Vol.45, n. 4 : pp. 479-490, December 2002

ISSN 1516-8913 Printed in Brazil

\title{
The Fate of Copepod Populations in the Paranapanema River (São Paulo, Brazil), Downstream from the Jurumirim Dam
}

\author{
Patricia Maria Mitsuka and Raoul Henry* \\ Department of Zoology; Institute of Biosciences; UNESP; C. P. 510; 18618-000; Botucatu - SP - Brazil
}

\begin{abstract}
The longitudinal changes in the structure of copepod populations were examined during the dry and rainy seasons in a $42 \mathrm{~km}$ stretch of the Paranapanema River downstream from the dam of the Jurumirim Reservoir. Samples were taken in the "lacustrine" zone of the reservoir near the dam, and also at 12 stations distributed in the middle and the lateral regions of the channel of the Paranapanema River downstream from the dam. The following species of Cyclopoida were found at the sites: Thermocyclops decipiens, Thermocyclops minutus, Paracyclops sp., Tropocyclops sp and Mesocyclops sp., and of Calanoida: Argyrodiaptomus furcatus, Notodiaptomus iheringi and Notodiaptomus conifer. In the reservoir sampling station, the copepod abundance during the dry and rainy seasons corresponded to 41 and $51 \%$ of the total zooplankton, respectively. This difference could be related to the rainfall and water level variations, and especially to the influence of variables such as water temperature, dissolved oxygen and chlorophyll-a contents. No significant differences in organism numbers were recorded among samples of zooplankton taken in the middle and near-bank parts of the river. In relation to longitudinal variation in the Paranapanema River stretch, a significant decrease in density and disappearance of some species were recorded $11 \mathrm{~km}$ downstream of the dam during the dry season. At the stations $32 \mathrm{~km}$ from the dam, a drastic reduction in copepod abundance was observed in the rainy season. These observations could be linked not only to environmental changes from lentic to lotic conditions, but also to the combination of certain factors such as current velocity, water outflow of the reservoir, and rainfall.
\end{abstract}

Key-words: Downstream, reservoir, copepod, abundance

\section{INTRODUCTION}

A discontinuity in the longitudinal gradient of rivers occurs when they are dammed. Changes in biotic and abiotic factors are evidenced in different intensities, according to the location of the dam in the river (Ward and Stanford, 1983). Studies on the fate of zooplanktonic and benthic communities in temperate regions in areas downstream from reservoirs have revealed a reduction in the densities of the organisms as well as a disappearance of some species in the regulated stretch of the river (Ward and Stanford, 1982a and 1982b; Zurek and Dumnicka, 1989; Pourriot et al., 1997). Chemical and hydrological factors, such as the operational management and the vertical position of the reservoir outlet in relation to the water level, and physical factors, such as the current velocity, can affect zooplankton development (Petts, 1984; Allan, 1995). The frequency and interaction of these factors interfere

* Author for correspondence 
with the structure and diversity of the planktonic organisms to a variable extent in sections of the rivers downstream from the dams (Chandler, 1937; Ward and Stanford,1983; Ward and Stanford, 1991; Townsend and Scarsbrook, 1997). However, the density of zooplankton organisms can recover with increasing distance from the dam because of the decrease in the current velocity and turbidity, and also increasing depth and light penetration in the rivers (Vannote et al., 1980; Palmer and O' Keefe, 1990). Some studies revealed that many zooplankton organisms are more tolerant to changes from a lentic to a lotic environment. This persistence is found in Copepoda, because they have a hard morphological structure and a great capacity for locomotion which enable them to tolerate the changes in habitat (Ward, 1975).

The aim of this work was to examine the spatial and temporal variations in the copepod community structure in the Paranapanema River, São Paulo, Brazil in a stretch downstream from the dam of Jurumirim Reservoir, and to determine the relationships between the copepod densities and the physical, chemical, and hydrological factors.

\section{STUDY AREA}

The Jurumirim Reservoir was shaped by the confluence of two main tributaries, the Paranapanema and Taquari Rivers, and it is the first of several other reservoirs, in a "cascade" sequence. The reservoir has a $446 \mathrm{~km}_{2}$ surface area and is used for water storage $\left(7,008 \mathrm{Hm}_{3}\right)$ and hydroelectric power. The maximum depth is $40 \mathrm{~m}$ and the water outlet is located between 7 to $19 \mathrm{~m}$ depth. At the dam zone, some limnological studies have been conducted (Henry, 1990, 1992, 1993a and 1993b, 1995; Henry and Maricato, 1996; Nogueira and Panarelli, 1997; Henry et al., 1998). At the downstream section, the Paranapanema River is less than $2 \mathrm{~m}$ deep, except at one site, the river narrows and the depth ranges from 30 to $40 \mathrm{~m}$.

\section{MATERIALS AND METHODS}

A sampling station was selected in the "lacustrine" zone of the Jurumirim Reservoir, where samples were collected at discrete depths from surface up to $25 \mathrm{~m}$ depth, with collections every $5 \mathrm{~m}$. In the 9 -
$18 \mathrm{~m}$ water column layer, collections were made every $3 \mathrm{~m}$, during two periods of the year, dry and rainy seasons. In the Paranapanema River, six stations (in mid-channel and near the right bank), located $0.75\left(\mathrm{P}_{1}\right), 7.35\left(\mathrm{P}_{2}\right), 11.5\left(\mathrm{P}_{3}\right), 17.0\left(\mathrm{P}_{4}\right)$, $32.8\left(\mathrm{P}_{5}\right)$ and $40 \mathrm{~km}\left(\mathrm{P}_{6}\right)$ from the dam of the Jurumirim Reservoir, were selected for surface water sampling (Fig.1). Following water variables were measured: temperature with a Toho Dentam thermistor; dissolved oxygen (Golterman and Clymo, 1969); water transparency (Secchi disk); the current velocity by an ELE currentmeter; the water $\mathrm{pH}$, alkalinity and conductivity (Golterman and Clymo, 1969); nitrogen forms such as total nitrogen, nitrate, and nitrite (Mackereth et al., 1978); phosphorus forms such as total phophorus, and dissolved total and inorganic phosphate (Strickland and Parsons, 1960); and "reactive" silicate and chlorophyll-a (Golterman and Clymo, 1969). Zooplankton samples at the reservoir sampling station were taken with pump equipment for water suction. Three hundred litres were pumped from discrete depths and filtered through a net $55 \mathrm{~mm}$ mesh size. In the river, a $10 \mathrm{~L}$ container was used to take the samples. The samples were fixed with $4 \%$ formol and the organisms were identified according to Sendacz and Kubo (1982), Matsumura-Tundisi (1986), Dussart (1987), and Dussart and Defaye (1995). Adult copepods were counted using a glass chamber in a Carl Zeiss stereomicroscope, while the young forms - nauplii and copepodids - were counted in a Sedgwick-Rafter chamber in a Carl Zeiss microscope $(1,000 \mathrm{x})$, up to 300 organisms (McCauley, 1984).

\section{RESULTS}

a) Physical, chemical and hydrological factors in the reservoir and in the river. A possible direct association between rainfall and water outflow was found (Fig.2). From April to August 1996, low precipitation and outflow were observed, while from December to February 1997, persistent and intense rains occurred and a significant increase in water outflow was recorded (from $65 \mathrm{~m}_{3 . \mathrm{S}-1}$ in June, to $1,042 \mathrm{~m}_{3 \mathrm{~S}-1}$ in January). Significant differences between the vertical profiles of water temperature and dissolved oxygen were found in the "lacustrine" zone of the Jurumirim Reservoir during the dry and rainy 
seasons (Fig.3 A and B, respectively). An apparent isothermy $(17.70 \mathrm{C})$ was evidenced in the dry season while during the rainy season, thermal stratification with a discontinuity in temperature from surface $(27.80 \mathrm{C})$ to bottom $\left(21_{0} \mathrm{C}\right)$ was recorded. Oxygen concentration (8.7mg.1 1 ) was homogeneous during the dry season in the water column. A clinograde profile of the dissolved oxygen was found in the rainy period, with higher oxygen concentration (mean value: 7.2mg.1-1) occurring in the epilimnetic layer (from 0 to $16 \mathrm{~m}$ depth). In the Paranapanema River, the temperature and water dissolved oxygen values showed a close relationship with those from Jurumirim Reservoir. Comparing the middle and the lateral regions of the six sampling stations of the Paranapanema River during the two periods of the year, no significant difference in the temperature and oxygen concentration was recorded. During the dry season, the temperature of all the stations was around $17 \circ \mathrm{C}$, while in the rainy season corresponded to 26。C. Oxygen concentration was above $8.0 \mathrm{mg} . \mathrm{l}_{-1}$ in the dry season and fluctuated between 7.0 and $8.0 \mathrm{mg} .1 \mathrm{l}$ in the rainy season.

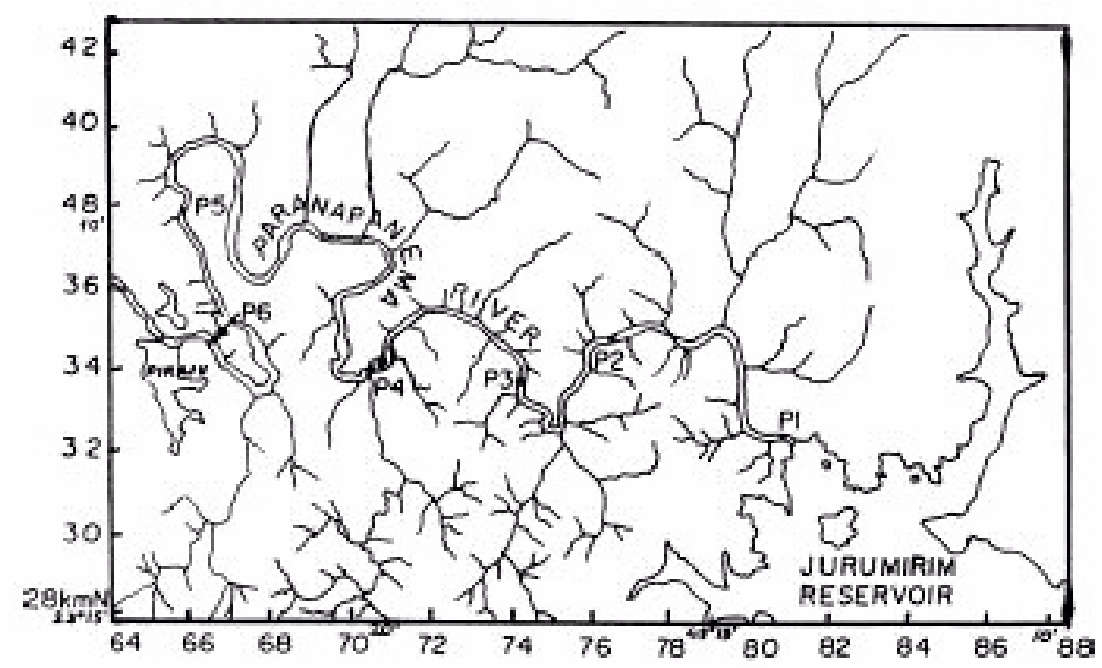

Figure 1 - Locations of the sampling stations in the Paranapanema River (P1 to P6 stations) and in the "lacustrine"zone of Jurumirim Reservoir (B station).

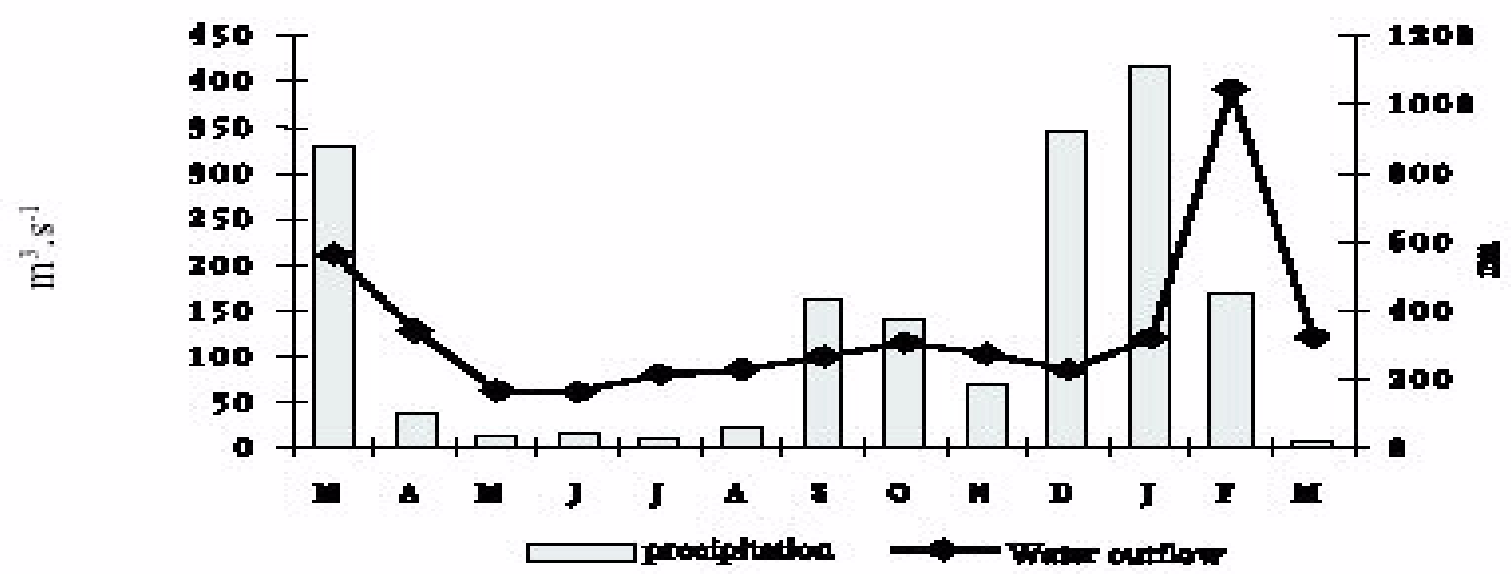

Figure 2 - Monthly variation of precipitation and outflow of the Jurumirim Reservoir from March 1996 to March 1997. 

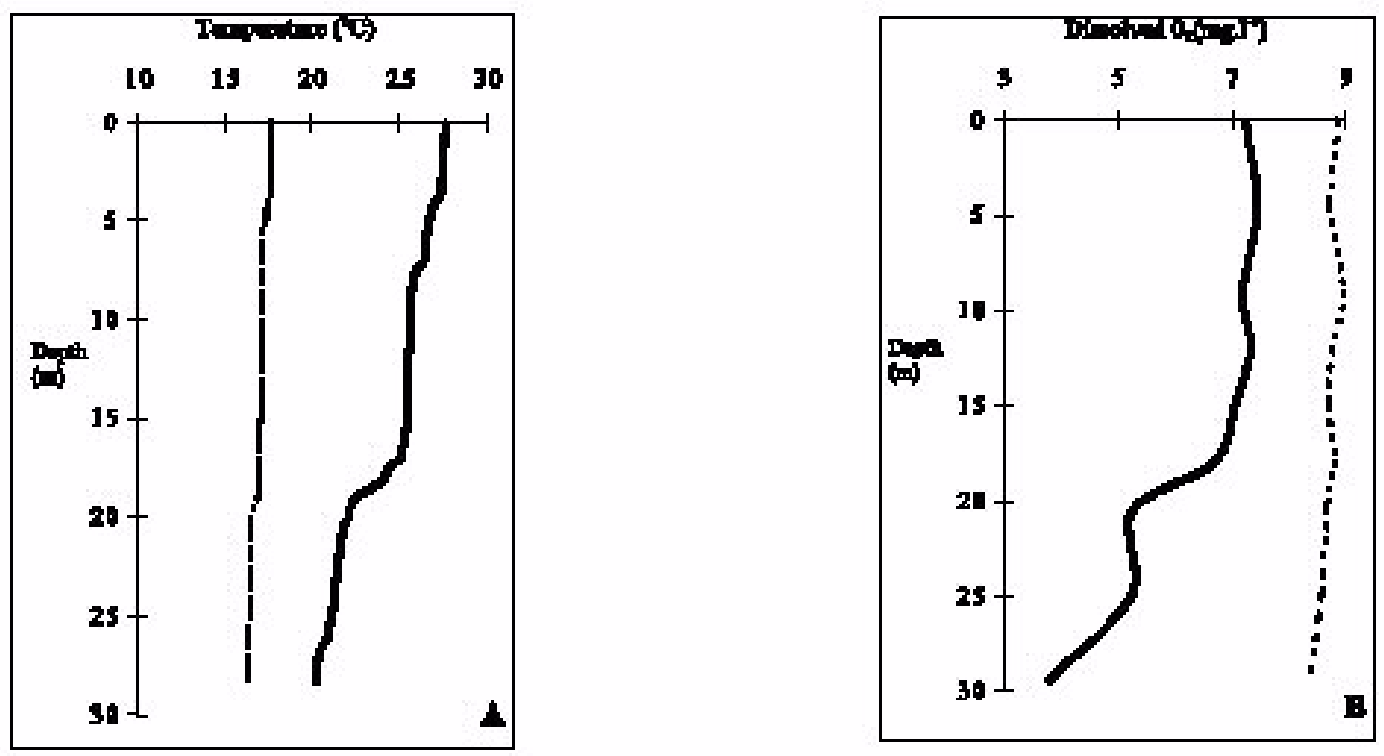

Figure 3 - Vertical profiles of temperature (A) and dissolved oxygen (B) in the water column of Jurumirim Reservoir during the dry (...) and rainy $(-)$ seasons.

The values of $\mathrm{pH}$, alkalinity, chlorophyll-a, suspended matter, conductivity, and total and dissolved nutrients of the water column of Jurumirim Reservoir are presented in Tables 1 (dry season) and 2 (rainy season). A Kruskal-Wallis non-parametric test was carried in order to show differences in the chemical and physical water variables between periods, stations, and regions (middle and lateral zones) of the Paranapanema River. The probability values $(\mathrm{P}<0.05)$, the determination $\left(\mathrm{R}_{2}\right)$, and variation coefficients (C.V.) are presented in Table 3. In general, the $\mathrm{pH}$ values were close to neutrality in both river and reservoir. In the reservoir, higher $\mathrm{pH}$ values were found during the dry season and they ranged from 6.2 to 6.6. In the rainy period, water $\mathrm{pH}$ was around 6.1 (except at the surface) while in the Paranapanema River, the values were very similar, 6.2 for the rainy season and 6.3 for the dry period. Alkalinity of the Paranapanema River and of the Jurumirim Reservoir was similar in the dry (mean value:0.39meq. 1 - 1 ) and the rainy (mean value: 0.40 meq.1-1) seasons. No significant variations in the water conductivity in the vertical (reservoir) and longitudinal (river) distributions were found. However, the two periods of the year differed at the two sites. In the lacustrine zone of Jurumirim Reservoir, conductivity was higher in the dry season (around $52.2 \mu \mathrm{S} . \mathrm{cm}_{-1}$ ) than in the rainy season (around $44.5 \mu \mathrm{S} . \mathrm{cm}_{-1}$ ). Downstream from of the dam, conductivity increased slightly from $53.2 \mu \mathrm{S} . \mathrm{cm}_{-1}$ in the rainy season to $56.8 \mu \mathrm{S} . \mathrm{cm}_{-1}$ in the dry period. Significant longitudinal variations $\left(\mathrm{R}_{2}=0.82\right)$ were found for conductivity in the Paranapanema River. The amount of suspended matter in the water column in the Jurumirim Reservoir was significantly higher in the rainy season (around $3.5 \mathrm{mg} . \mathrm{l}_{-1}$ ) than in the dry period ( $<1.0 \mathrm{mg} . \mathrm{l}_{-1}$ ). In the Paranapanema River, only at station $\mathrm{P}_{1}$ did the concentration of suspended matter show similar values to those in the reservoir. Concentrations of suspended matter in the river were higher in the rainy season (around $\left.5.0 \mathrm{mg} . \mathrm{l}_{-1}\right)$ than in the dry period. The mean concentration of chlorophyll-a in the water column of the reservoir was two times higher in the dry season (1.6mg.m-3) than in the rainy period (0.8mg.m-3). The vertical distribution of chlorophyll-a showed small oscillations from surface to a depth of $25 \mathrm{~m}$. However, a substantial increase was observed near the bottom. In comparison with data from the reservoir, the chlorophyll-a values were higher in the Paranapanema River (around 2.0mg.m-3) and longitudinal variations were observed. During the dry season, the chlorophyll-a concentration 
decreased slowly from station P1 to station P4. Then, there was an increase up to station $\mathrm{P}_{6}$. A gradual increase in the chlorophyll-a concentrations was found in the rainy period from station $\mathrm{P}_{1}$ to station $\mathrm{P}_{5}$ and then, a decline occurred at station $\mathrm{P}_{6}$. The current velocity in the Paranapanema River showed significant differences $\left(\mathrm{R}_{2}=0.72\right)$ between the middle and lateral regions and also between stations. Differences were also evident between the two periods of the year, but the statistical analysis showed no significant variations. Concerning the regions of the river, the mean velocity in the middle $(0.43 \mathrm{~m}$. $\mathrm{s}-1)$ was higher than in the lateral zones $(0.15 \mathrm{~m} . \mathrm{s}-1)$. In both periods of the year, the current velocity showed the same longitudinal pattern of variation (Fig.4). The current velocity increased up to station $\mathrm{P}_{3}$, then decreased from station $\mathrm{P}_{4}$, because of the influence of the Piraju Reservoir, the second reservoir in the cascade series. In the Jurumirim Reservoir, the water transparency in the dry season $(2.48 \mathrm{~m})$ was lower than in the rainy period $(4.6 \mathrm{~m})$. In the Paranapanema River, the values in the rainy season (around $2.5 \mathrm{~m}$ ) were also higher than in the dry period $(2.0 \mathrm{~m})$. In relation to the total and dissolved nutrient concentrations, significant differences were only found between the two seasons of the year in reservoir and in the river. Higher values were found in the rainy period than in the dry season. Small variations in the vertical (Jurumirim Reservoir) and the longitudinal (Paranapanema River) distribution of nutrients were also observed (Tab.1 and 2).

b) Zooplankton composition and density In the Jurumirim Reservoir and in the Paranapanema River, 8 different taxa of Copepoda were found: 3 species of Calanoida (Argyrodiaptomus furcatus, Notodiaptomus iheringi, Notodiaptomus conifer) and 5 species of Cyclopoida (Mesocyclops cf. longisetus, Thermocyclops decipiens, Thermocyclops minutus, Tropocyclops sp, Paracyclops sp.) Harpacticoids were also recorded but not identified. An apparent similarity in copepod species richness was observed between the sampling stations of the Paranapanema River in the dry season (Fig.5-A). However, this pattern changed during the rainy period, because some species disappeared with increasing distance from Jurumirim Reservoir (Fig.5-B).

Table 1 - Values of the chemical factors in the water column of Jurumirim Reservoir during the dry season.

\begin{tabular}{|c|c|c|c|c|c|c|c|c|c|c|}
\hline $\begin{array}{c}\text { Dept } \\
\text { h } \\
(\mathbf{m}) \\
\end{array}$ & $\mathrm{pH}$ & $\begin{array}{c}\text { Alkalinity } \\
\left(\text { meq. }^{-1}\right)\end{array}$ & $\begin{array}{c}\text { Suspended } \\
\text { Matter } \\
\left(\text { mg. }^{-1}\right)\end{array}$ & $\begin{array}{c}\text { Conductivity } \\
\left(\mu \mathrm{S} . \mathrm{cm}^{-1}\right)\end{array}$ & $\begin{array}{c}\text { Chlorophyll-a } \\
\left(\mathrm{mg} \cdot \mathrm{m}^{-3}\right)\end{array}$ & $\begin{array}{c}\mathrm{NO}_{3}^{-} \\
\left(\mathrm{mg}^{-1} \mathbf{1}^{-1}\right)\end{array}$ & $\begin{array}{c}\mathrm{NO}_{2}^{-} \\
\left(\mathrm{mg.1}^{-1}\right)\end{array}$ & $\begin{array}{l}\mathrm{PO}_{4}^{3-} \text { tot } \\
\left(\mathrm{mg}^{-1}{ }^{-1}\right)\end{array}$ & $\begin{array}{c}\mathrm{TN} \\
\left(\mathrm{mg.1}^{-1}\right)\end{array}$ & $\underset{\left(\mathrm{mg}^{-1} 1^{-1}\right)}{\mathrm{SiO}_{3}^{-}}$ \\
\hline 0.0 & 6.3 & 0.39 & 7.4 & 79.0 & 1.29 & 8.8 & 1.6 & 8.9 & 348.6 & 3.0 \\
\hline 4.5 & 6.6 & 0.40 & 0.97 & 53.0 & 1.74 & 11.0 & 1.8 & 8.0 & 355.8 & 2.9 \\
\hline 9.0 & 6.4 & 0.40 & 1.0 & 52.0 & 1.68 & 10.7 & 1.6 & 7.7 & 263.4 & 3.0 \\
\hline 12 & 6.3 & 0.40 & 1.0 & 52.0 & 1.68 & 10. & 1.6 & 9.2 & 313.0 & 2.9 \\
\hline 15 & 6.4 & 0.40 & 0.80 & 52.0 & 1.29 & 10.4 & 0.8 & 8.7 & 317.0 & 2.9 \\
\hline 18 & 6.3 & 0.40 & 0.96 & 52.0 & 1.63 & 9.1 & 2.0 & 9.8 & 363.8 & 3.0 \\
\hline 20.5 & 6.4 & 0.40 & 1.0 & 52.0 & 1.63 & 7.4 & 2.5 & 12.3 & 360.4 & 2.9 \\
\hline 25 & 6.2 & 0.40 & 0.80 & 52.0 & 1.96 & 9.8 & 2.0 & 9.1 & 429.4 & 3.0 \\
\hline 29.5 & 6.2 & 0.40 & 0.90 & 52.0 & 2.80 & 8.8 & 1.1 & 9.2 & 415.0 & 2.9 \\
\hline
\end{tabular}

Table 2 - Values of the chemical factors in the water column of Jurumirim Reservoir during the rainy season.

\begin{tabular}{|c|c|c|c|c|c|c|c|c|c|c|}
\hline $\begin{array}{c}\text { Depth } \\
\text { (m) }\end{array}$ & pH & $\begin{array}{l}\text { Alkalinity } \\
\left(\text { meq. }^{-1}\right)\end{array}$ & $\begin{array}{c}\text { Suspended } \\
\text { Matter } \\
\left(\mathrm{mg.1}^{-1}\right)\end{array}$ & $\begin{array}{c}\text { Conductivity } \\
\left(\mu{\left.\mathrm{S} . \mathrm{cm}^{-1}\right)}^{-1}\right.\end{array}$ & $\begin{array}{c}\text { Chlorophyll-a } \\
\left(\mathrm{mg} \cdot \mathrm{m}^{-3}\right)\end{array}$ & $\begin{array}{c}\mathrm{NO}_{3}^{-} \\
\left(\mathrm{mg}^{-1} 1^{-1}\right)\end{array}$ & $\begin{array}{c}\mathrm{NO}_{2}^{-} \\
\left(\mathrm{mg}^{-1} \mathbf{1}^{-1}\right)\end{array}$ & $\begin{array}{l}\mathrm{PO}^{3-}{ }_{4} \text { tot } \\
\left(\mathrm{mg}^{-1} 1^{-1}\right)\end{array}$ & $\begin{array}{c}\text { TN } \\
\left(\mathrm{mg.1}^{-1}\right)\end{array}$ & $\begin{array}{l}\mathrm{SiO}_{3}^{-} \\
\left(\mathrm{mg.1}^{-1}\right)\end{array}$ \\
\hline 0.0 & 6.6 & 0.40 & 2.7 & 48.9 & 1.00 & 6.7 & 3.1 & 11.2 & 289.7 & 4.8 \\
\hline 4.5 & 6.2 & 0.40 & 3.0 & 42.7 & 1.12 & 6.6 & 3.4 & 10.2 & 333.0 & 4.8 \\
\hline 9.0 & 6.1 & 0.40 & 3.4 & 42.7 & 1.01 & 7.5 & 3.4 & 11.2 & 283.4 & 4.6 \\
\hline 12 & 6.2 & 0.40 & 3.2 & 44.5 & 0.78 & 6.4 . & 3.4 & 10.2 & 512.1 & 4.9 \\
\hline 15 & 6.1 & 0.40 & 3.5 & 44.5 & 0.89 & 6.7 & 2.3 & 11.7 & 687.7 & 4.5 \\
\hline 18 & 6.1 & 0.40 & 2.4 & 44.5 & 0.45 & 6.1 & 1.7 & 10.4 & 516.0 & 4.5 \\
\hline 20.5 & 6.1 & 0.41 & 3.5 & 44.5 & 0.56 & 5.9 & 1.7 & 16.5 & 641.5 & 4.8 \\
\hline 25 & 6.1 & 0.41 & 3.7 & 45.0 & 0.78 & 7.1 & 1.0 & 7.80 & 239.5 & 4.4 \\
\hline 29.5 & 6.2 & 0.43 & 13.3 & 49.5 & 6.74 & 6.8 & 0.7 & 11.7 & 240.0 & 4.6 \\
\hline
\end{tabular}


Table 3 - Values of probability (Pr), coefficients of determination $\left(\mathrm{R}^{2}\right)$ and variation (C.V.) of abiotic and biotic factors.

\begin{tabular}{|c|c|c|c|c|c|}
\hline \multirow[b]{2}{*}{ FACTOR } & \multicolumn{3}{|c|}{ Pr } & \multirow[b]{2}{*}{$\mathbf{R}^{2}$} & \multirow[b]{2}{*}{ C.V.(\%) } \\
\hline & REGION & STATION & PERIOD & & \\
\hline Temperature $\left({ }^{\circ} \mathrm{C}\right)$ & 0.550 & 0.025 & 0.0001 & 0.99 & 1.25 \\
\hline Oxygen $\left(\mathrm{mg}^{-1} \mathrm{1}^{-1}\right)$ & 0.772 & 0.103 & 0.0001 & 0.79 & 4.16 \\
\hline $\mathrm{pH}$ & 0.755 & 0.591 & 0.041 & 0.35 & 2.00 \\
\hline Alkalinity (meq. $1^{-1}$ ) & 1.000 & 0.378 & 0.300 & 0.30 & 0.95 \\
\hline Conductivity $\left(\mu \mathrm{S} . \mathrm{cm}^{-1}\right)$ & 0.625 & 0.0001 & 0.001 & 0.82 & 4.25 \\
\hline Suspend.Matter(mg. $\left.1^{-1}\right)$ & 0.910 & 0.177 & 0.338 & 0.37 & 0.37 \\
\hline Current velocity $\left(\mathrm{m} \cdot \mathrm{s}^{-1}\right)$ & 0.0007 & 0.008 & 0.246 & 0.72 & 56.7 \\
\hline Chlorophylla-a (mg.m ${ }^{-3}$ ) & 0.825 & 0.040 & 0.305 & 0.50 & 31.7 \\
\hline $\mathrm{NO}_{3}^{-}\left(\mu \mathrm{g} \cdot 1^{-1}\right)$ & 0.693 & 0.002 & 0.002 & 0.72 & 10.8 \\
\hline $\mathrm{NO}_{2}^{-}\left(\mu \mathrm{g} \cdot 1^{-1}\right)$ & 0.767 & 0.136 & 0.074 & 0.45 & 23.0 \\
\hline Total nitrogen $\left(\mu \mathrm{g} .1^{-1}\right)$ & 0.357 & 0.282 & 0.767 & 0.55 & 21.6 \\
\hline Dissol.total $\mathrm{PO}_{4}^{3-}\left(\mu \mathrm{g} .1^{-1}\right)$ & 0.864 & 0.307 & 0.071 & 0.39 & 18.8 \\
\hline Total phosphorus $\left(\mu \mathrm{g} . .^{-1}\right)$ & 0.792 & 0.001 & 0.0001 & 0.69 & 21.7 \\
\hline Inorg. $\mathrm{PO}_{4}{ }^{3-}\left(\mu \mathrm{g} .1^{-1}\right)$ & 0.650 & 0.383 & 0.003 & 0.27 & 20.7 \\
\hline $\mathrm{SiO}^{-}\left(\mathrm{mg}^{4} \mathrm{l}^{-1}\right)$ & 0.429 & 0.335 & 0.069 & 0.68 & 10.9 \\
\hline
\end{tabular}

A predominance of Copepoda was observed in the $0-9 \mathrm{~m}$ layer of the lacustrine part of the reservoir (Fig.6). An almost similar distribution in the water column was recorded in the mixing period of the reservoir (dry season). In the rainy period, copepod densities decreased below $15 \mathrm{~m}$ depth, a layer where temperature and dissolved oxygen decreased (Fig.2). The influence of both environmental variables on the distribution of zooplanktonic organisms appears to be considerable. The copepod density was higher during the rainy period with a "peak" at the surface, because of the high number of larval forms. In Jurumirim Reservoir, cyclopoid comprised $61 \%$ and $23 \%$ of all the Copepoda in the dry and rainy seasons, respectively. The high density of Cyclopoida during the dry period resulted from the numeric predominance of Thermocyclops minutus (8,339 org.m-3) and the presence of nauplii and copepodids. On the other hand, calanoids were dominant during the rainy season ( $77 \%$ of total numbers of Copepoda).
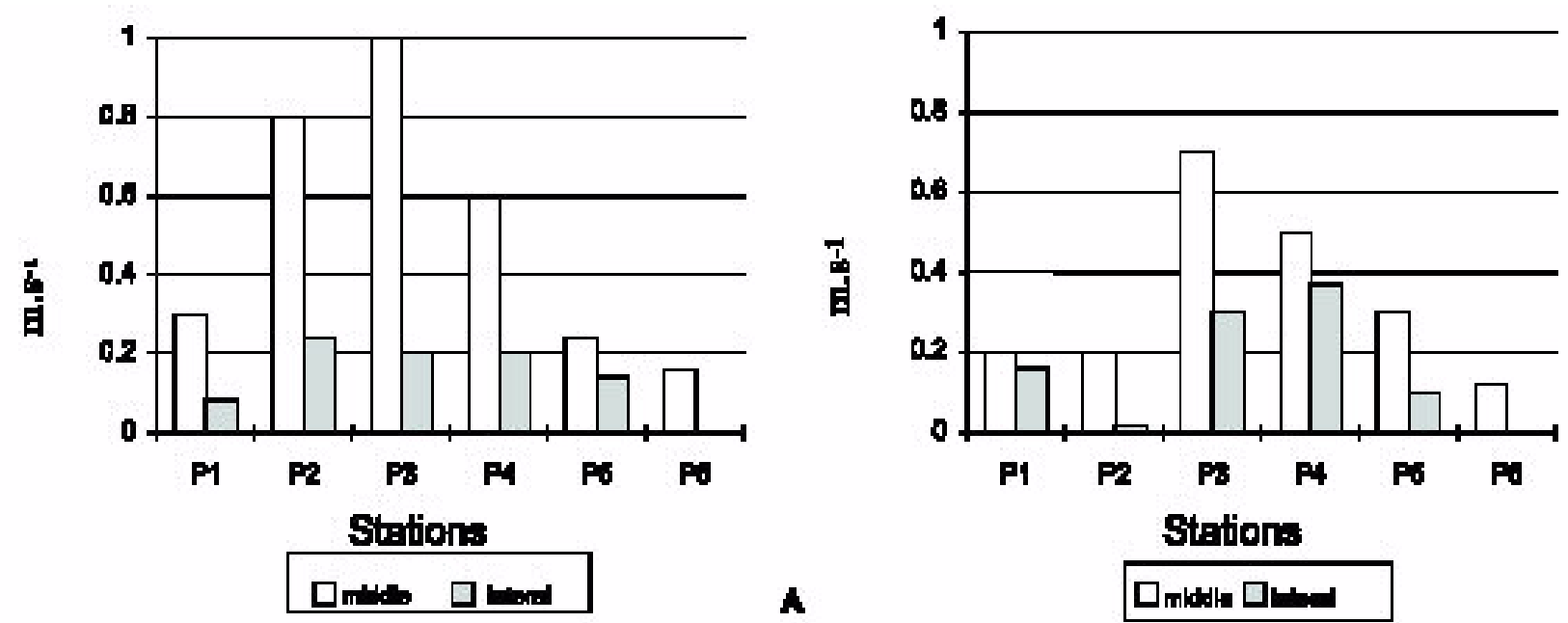

Figure 4 - Longitudinal variation of current velocity on the lateral and the middle regions of the channel in Paranapanema River during the dry (A) and rainy (B) seasons. 

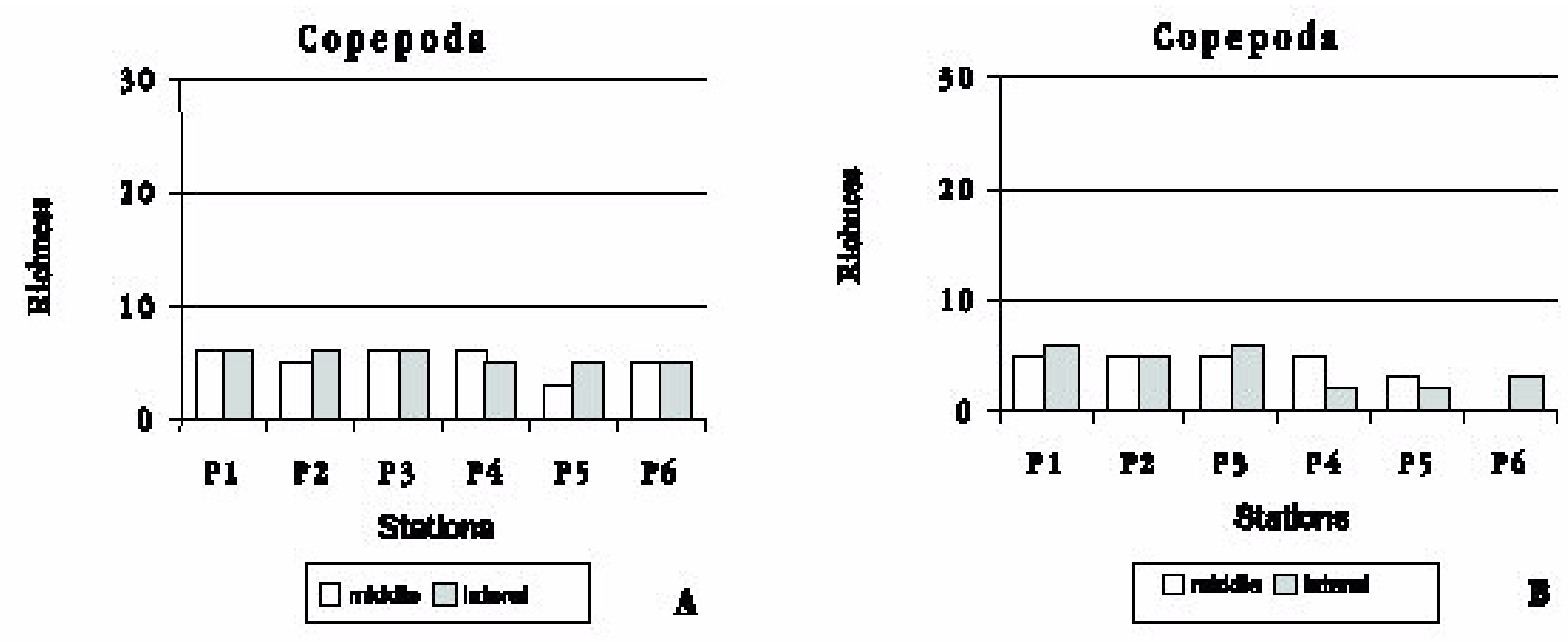

Figure 5 - Longitudinal distribution of Copepoda richness in the lateral and middle zones of the channel of Paranapanema River during the dry (A) and rainy (B) seasons.

Notodiaptomus iheringi was the most abundant species $(2,607$ org.m-3), and together with the larval forms, exibited a density corresponding to $73.8 \%$ of all the organisms. The frequency of occurrence of the calanoid species during the two periods of the year was $100 \%$, except for Notodiaptomus conifer, which occurred in only $44 \%$ of the samples during the dry period. In Jurumirim Reservoir, harpacticoids occurred only during the rainy season. The density corresponded to 37 org.m-3, including adults and nauplii. The copepods of the Paranapanema River were composed of planktonic species from the Jurumirim Reservoir. Tropocyclops sp. occurred only during the dry season, while Paracyclops sp. were observed only during the rainy period. In relation to the frequency of occurrence, nauplii and copepodids of both copepod orders were found in all samples.

Considering the Calanoida, Notodiaptomus iheringi, was dominant in both periods of the year. Thermocyclops minutus, Thermocyclops decipiens, and Mesocyclops sp were present in 100, 91, and $58 \%$ of the samples, respectively, during the dry period. During the rainy season, the same sequence of predominance was observed, but with a lower frequency $(67,67$ and $17 \%$, respectively). Larval stages (nauplii and copepodids) were highly important for the numeric density of Copepoda. Calanoids in initial stages of development showed high abundance during the dry period (Fig.7). Conversely, during the same season, the Calanoida adults were numerically more important than their larval stages. The dominant species during this period was Notodiaptomus iheringi (1,214 org.m-3), followed by Argyrodiaptomus furcatus (697 org.m-3) and Notodiaptomus conifer (193 org.m-3). In the rainy season, the same sequence of dominance was observed, but with a lower density of organisms.

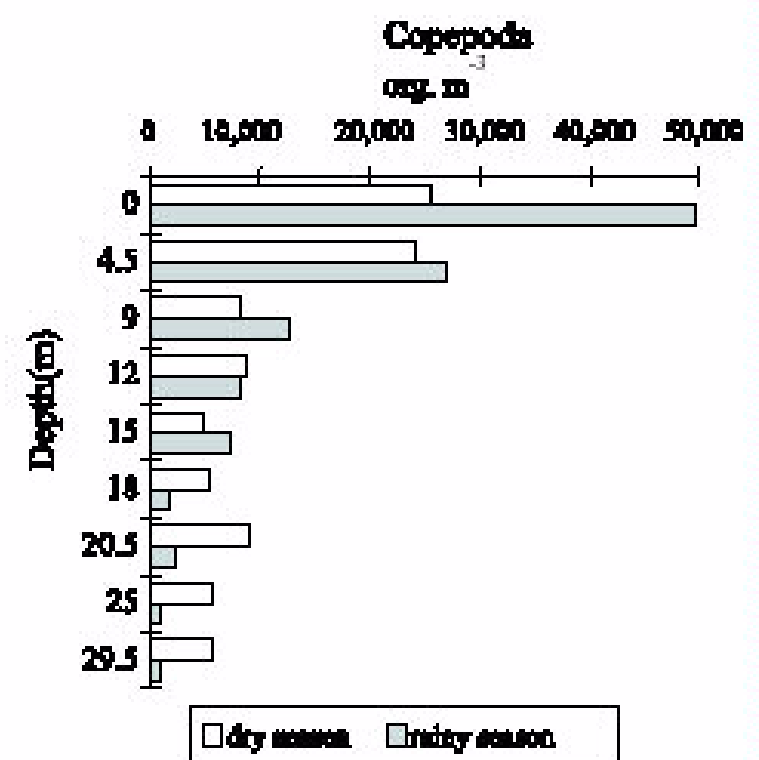

Figure 6 - Vertical distribution of Copepods in Jurumirim Reservoir during the dry and rainy seasons. 
Nauplii and copepodids of Cyclopoida constituted $64 \%$ of all the Copepoda, and the adults of Calanoida (1,147 org.m-3) exhibited a higher density compared to adults of Cyclopoida (178 org.m-3) during the rainy season (Figs. 8 and 9). In general, the densities of adults of Cyclopoida were very low in both periods of the year (Fig.8). Only at station $\mathrm{P}_{1}$, high abundances of Thermocyclops minutus and Thermocyclops decipiens were found during the dry season. In the Paranapanema River, the abundance of Harpacticoida increased from 279 org.m-3 in the dry period to 403 org.m-3 in the rainy season. There was a high number of organisms in the dry season, compared with the rainy period, and also higher density at station $\mathrm{P}_{1}$ (the first after the dam). From station $\mathrm{P}_{1}$ to station $\mathrm{P}_{4}$, there was a reduction on the density of adults, as well as a higher density of organisms in the lateral region, compared to the region in the middle of the channel during the dry period. A drastic decrease in densities was found during the rainy period for Calanoida and Cyclopoida, from station $\mathrm{P}_{5}$ (Figs.8 and 9).
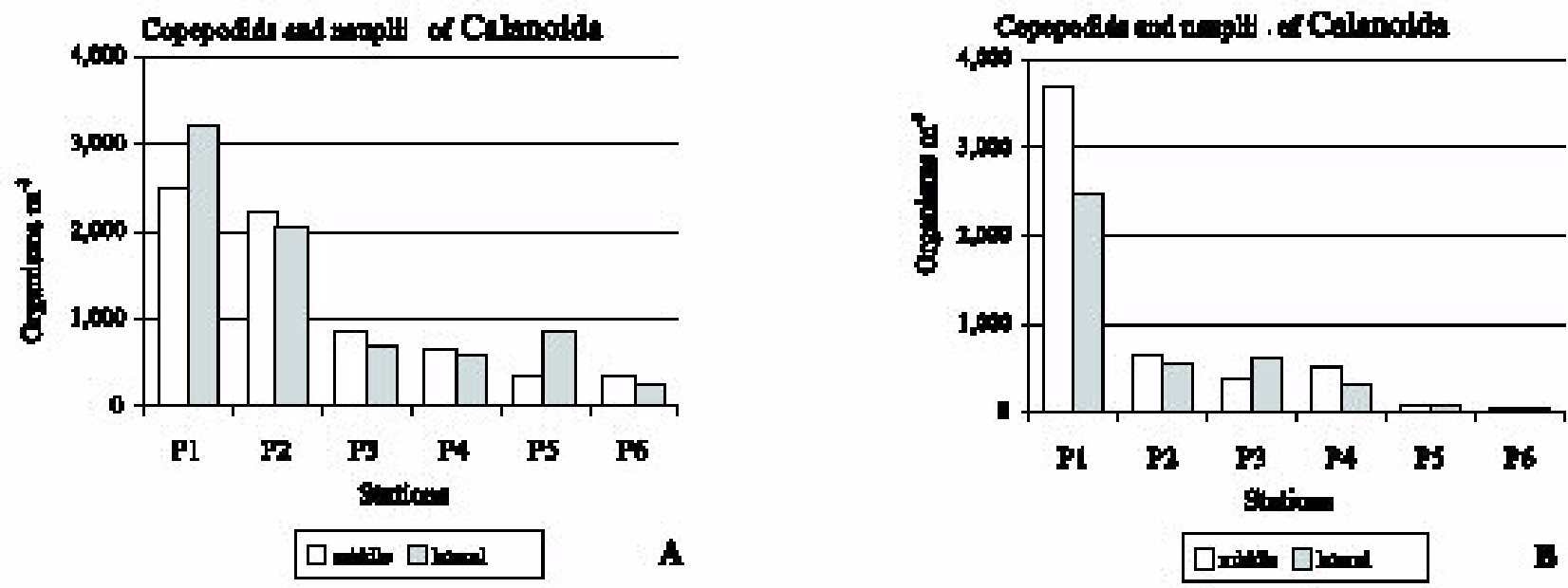

Figure 7 - Longitudinal distribution of density of copepodids and nauplii of Calanoida in the Paranapanema River in the dry (A) and rainy (B) seasons.
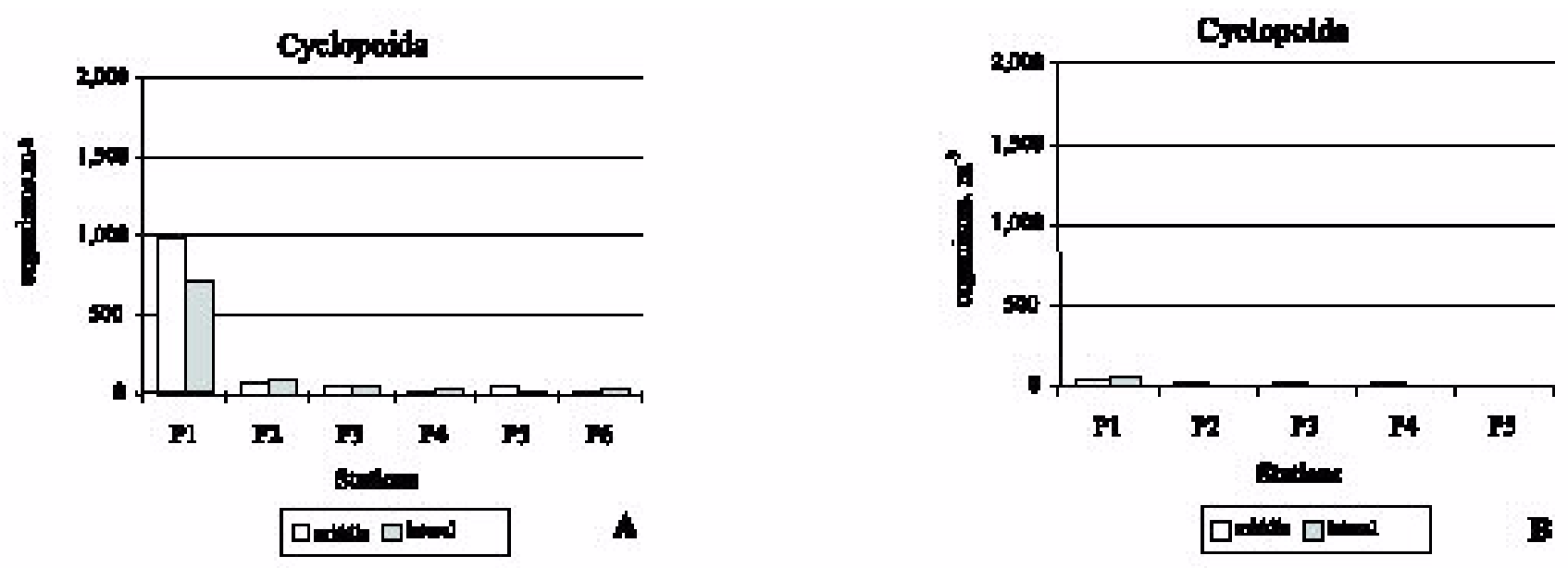

Figure 8 - Longitudinal distribution of density of adults of Cyclopoida in the Paranapanema River during the dry (A) and rainy (B) seasons. 

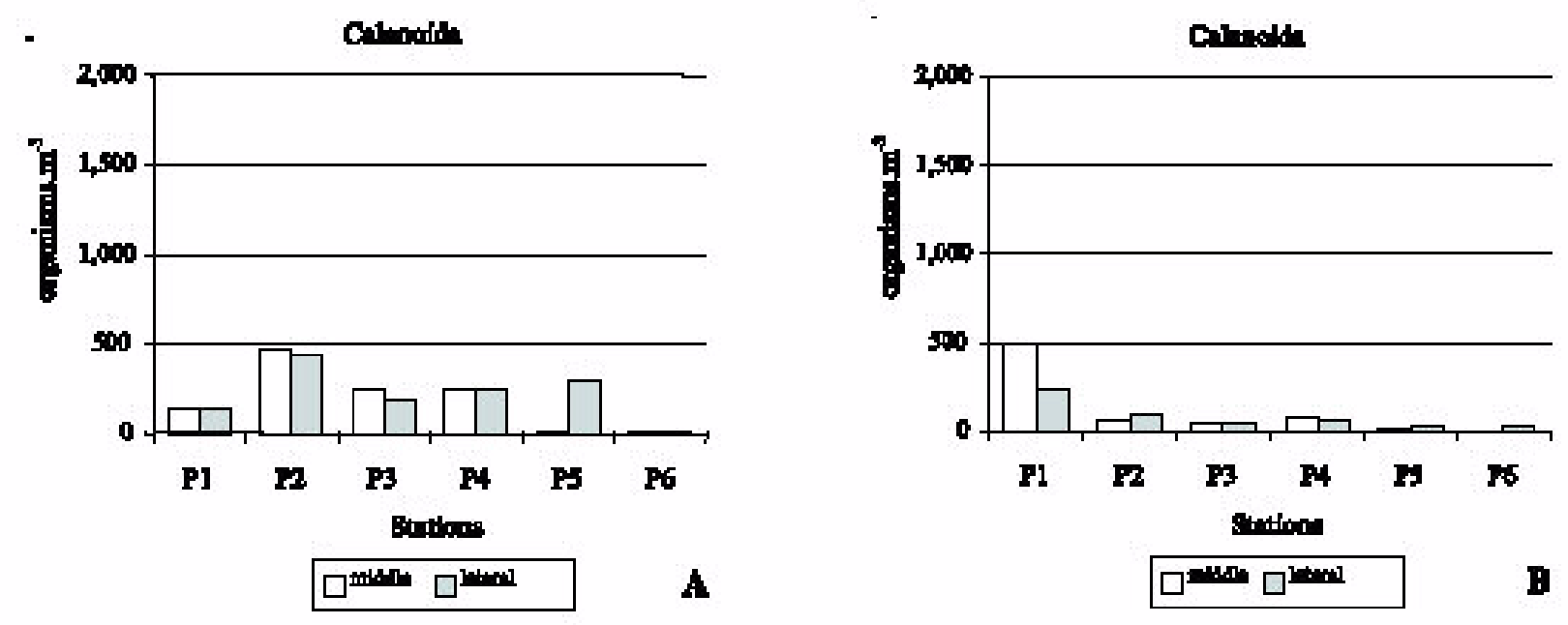

Figure 9 - Longitudinal distribution of density of adults of Calanoida in the Paranapanema River on the dry (A) and rainy $(\mathrm{B})$ seasons.

\section{DISCUSSION}

Patterns in the composition and variation of the relative abundance in zooplankton populations are hard to explain, because of the complexity and variety of biotic and abiotic interactions which control the dynamics of the community in lacustrine and lotic environments (Bernardi, 1979; Tonhasca Jr., 1994; Lansac-Toha et al.,1995). In tropical rivers, changes in the abiotic and biotic factors are not cyclic. The variations in water discharge produce pulses of energy and matter, either during the low or high water level periods (Neiff, 1996). Zooplankton diversity in lotic environments can vary on a regional scale. Rivers can transport species from lakes, reservoirs, marginal lakes of their drainage basin and also from other tributaries (Barbosa et al., 1997). There was no difference in composition between Copepoda from the Jurumirim Reservoir and the Paranapanema River. The community of Copepoda represented by 3 species of Calanoida (A.furcatus, N.iheringi and N.conifer), 5 Cyclopoida species (Mesocyclops sp., T. decipiens, T.minutus, Tropocyclops sp and Paracyclops sp) and Harpacticoids was already described in a study of Nogueira and Panarelli (1997), of the vertical migration of zooplankton in the "lacustrine" zone of Jurumirim Reservoir. In lotic ecosystems, the hydrodynamic and abiotic characteristics in mid channel differ significantly from those of the nearbank zones. Thus, in the edge of the rivers benthic and periphytic algae frequently occur and can influence the species richness of the zooplanktonic community. The rivers -environments with high water renewal - exhibit a complexity of marginal habitats which sustain high biological diversity (Payne, 1986). However, the richness values for copepods of the lateral region of the Paranapanema River, compared with those of the middle of the channel, showed no significant differences (Fig.5). Also, no significant differences in the abundance of copepods from the two regions of the river were found, despite the differences in the longitudinal hydrodynamic characteristics, such as the lower current velocity, and higher plant food availability (estimated by chlorophyll-a content) which can support their development (Hynes, 1970). According to Vasquez and Rey (1989), an inverse relationship between water discharge and plankton density occurs in the Orinoco River, Venezuela. During low water level periods, zooplankton densities near the banks in the border of the Orinoco River differ significantly from those in midchannel. A very homogenous distribution of zooplankton was also observed along the Orinoco River and some of its tributaries (Vasquez and Rey, 1989). In the Paranapanema River, the situation is not the same because of the highly different water discharges, from one day to the other, in function of eletric power generation. In relation to the organism density in the two periods of the year, there was a higher abundance in the dry season compared to the rainy season, in the Jurumirim Reservoir as in the Paranapanema River. Cyclopoida was the 
dominant group in the dry season, as observed in the study by Nogueira and Panarelli (1997) in the Jurumirim Reservoir. Concerning the longitudinal distribution, the distribution of abundance of the Copepoda varied in the Paranapanema River. A continuous reduction of zooplankton density at the downstream section of the dam of Jurumirim Reservoir was observed along the $42 \mathrm{~km}$ stretch of the Paranapanema River. In the dry period, the copepod density in the six sampling stations of Paranapanema River corresponded to 65, 36.8, 19, $16.7,4.4$, and $2.4 \%$ of total organisms proceeding from the reservoir,collected at $0.75,7.35,11.5,17$, 32.8 , and $40 \mathrm{~km}$ from the dam, respectively. In the rainy season, the copepods density showed lower values which corresponded to $36.2,7.6,7.2,2.5$, 2.1 , and $0.9 \%$ of the organisms proceeding from the reservoir. In the rainy period, a drastic decrease in copepod density was evident in the last two stations $\left(\mathrm{P}_{5}\right.$ and $\left.\mathrm{P}_{6}\right)$, as in samples collected in mid-channel as well as from the lateral zone of the Paranapanema River. The persistence of adults in the two most distant stations from the dam represented, in this period, 2.1 and $0.9 \%$ of the total copepods found in the reservoir. Current velocity appears to have an important role in longitudinal pattern of variation of the copepod density. Firstly, a slow increase occurred up to station $\mathrm{P}_{3}$, and then, a reduction in the current velocity was observed. Thus, it affected only the abundance of copepod in stations more distant from the dam (Fig.5). Comparing the two seasons, a same pattern was recorded but, lower velocity was found during the rainy season. The current velocity affects the availability of food resources through the removal of nutrients and nutritive compounds of biotic community. The current velocity also perfoms a direct physical action which affects the organisms in the water column as well as near the bottom (Allan, 1995). Thus, the current velocity is a selective factor because it produces modifications on the organism numbers as well as on the species diversity. Besides the current velocity, the water level fluctuation of the river affects the plankton communities. The changes on water level conduct to a modification on the density and species composition, and are originated from the physical, chemical and biological patterns of the aquatic environment. The temperature has also some effects on the activity and life cycles of the biota of lotic ecosystems. Moreover, the temperature affects egg development and growth of juvenile forms of zooplankton species. Seasonal modifications on temperature frequently induce a development and a synchrony on the life cycles of these organisms. Therefore, the changes on density and composition can be attributed mainly to physical variables as current velocity, water discharge and turbidity, and also to biological causes, as predation and competition (Urabe, 1989). Although many factors can influence the zooplankton density and composition, the water level in rivers (and thus the discharge) is one of the most important control factors (Bonetto, 1986). The zooplankton disappearance from the Blue Nile, Africa, was attributed to the increase in the suspended matter concentration (Payne, 1986). The large amount of particles in suspension directly affected the zooplankton, blocking the respiration and locomotion apparatus and, indirectly - through the decrease in light penetration, acting as a limiting factor for algae production. Howewer, the changes suspended matter can cause only certain modifications in the composition of zooplankton communities. Pourriot et al. (1997) stressed that the development time of the zooplankton together with the water retention time in lotic systems, are the main factors that cause a decrease in the density of this animal group. Only organisms with fast growth and high reproduction rates, as such rotifers and small cladocerans (e.g.,Chydoridae) can increase populations when the residence time of rivers is low (Hynes,1970). According to Palmer and O'Keeffe (1990), the benthic fauna can recompose, with increasing distance from the dam, because the typical characteristics of rivers reappear. However, recovery in abundance of copepods was not observed in the Paranapanema River, because only harpacticoids occurred significantly at the last sampling station $\left(\mathrm{P}_{6}\right)$. The occurrence of a reduction of planktonic organisms in regulated rivers is linked not only to one factor, but to a combination of factors that depend on the characteristics of the river stretch. In the Paranapanema River, current velocity was the main factor controlling the longitudinal variation in the copepod density and, indirectly the water discharge and the algae biomass (estimated by the chlorophyll-a).

\section{ACKNOWLEDGEMENTS}

The authors are grateful to $\mathrm{CNPq}$ for financial support, to Hamilton A.Rodrigues for his help in 
the field work; to José Mário Pisani for drawing the map; to Aparecida dos Santos Oliveira for typing the manuscript; to Célia Guimarães, for the English revision, and to Marcos Gomes Nogueira for the comments and suggestions.

\section{RESUMO}

As mudanças longitudinais na estrutura das populações de copépodos foram examinadas durante as estações seca e chuvosa num trecho de $42 \mathrm{~km}$ do Rio Paranapanema, a jusante da Represa de Jurumirim. Amostras foram coletadas na zona "lacustre" da represa próxima à barragem e também em 12 estações situadas na região lateral e no meio do canal do Rio Paranapanema, a jusante da barragem. As seguintes espécies de Cyclopoida foram encontradas nos locais: Thermocyclops decipiens, Thermocyclops minutus, Tropocyclops sp Paracyclops sp., e Mesocyclops sp., e de Calanoida: Argyrodiaptomus furcatus, Notodiaptomus iheringi e Notodiaptomus conifer. $\mathrm{Na}$ represa, a abundância de copépodos durante as estações seca e chuvosa correspondeu a 41 e $51 \%$ do zooplâncton total, respectivamente. Esta diferença pode ser relacionada às variações de precipitação e nivel de água, e especialmente à influência de variáveis como temperatura da água, concentrações de oxigênio dissolvido e clorofila-a. Nenhuma diferença significativa nas densidades de organismos foi encontrada entre amostras de zooplâncton coletadas na região lateral e no meio do rio. Em relação à variação longitudinal no trecho do Rio Paranapanema, uma diminuição significativa na densidade e o desaparecimento de algumas espécies foram registradas a partir de 11 $\mathrm{km}$ da barragem durante a estação seca. Nas estações localizadas a partir de $32 \mathrm{~km}$ da barragem, uma redução drástica na abundância de copépodos foi observada no período chuvoso. Estas observações podem estar associadas não somente à mudança ambiental de condições lênticas para lóticas, mas também à combinação de certos fatores como velocidade da correnteza, vazão de água e precipitação.

\section{REFERENCES}

Allan, J. D. (1995), Stream ecology - Structure and function of running waters. Chapman and Hall, London. 388 pp.
Barbosa, F. A. R.; Souza, E. M. M.; Renaut, G. P. C. P.; Vieira, F.; Rocha, L. A.; Maia-Barbosa, P. M.; Oberdá, S. M. and Mingott, S. A. (1997), Impactos Antrópicos e Biodiversidade aquática. In: Paula, J. A. (ed). Biodiversidade, população e economia. UFMG, Belo Horizonte. pp. 345-454.

Bernardi, R. (1979), Some problems in the study of population dynamics of zooplankton. Bull. Zool., 46, 179-189.

Bonetto, A. A. (1986), The Paraná river System. In: Bryan, R. and Walker, K. F.(Eds.). The ecology of river systems. Series Editor (Monographiae biologica). pp.541-555.

Carvalho, M. L. (1983), Efeitos da flutuação do nível da água sobre a densidade e composição do zooplâncton em um lago de várzea da Amazônica, Brasil. Acta Amazonica, 13715-724.

Chandler, D. C. (1937), Fate typical lake plankton in streams. Ecol. Monogr., 7, 446-479.

Dussart, B. H. (1987), Sur quelques Mesocyclops (Crustacea, Copepoda) d'Amérique du Sud. Amazoniana, 10, 149-161.

Dussart, B. H. and Defaye, D. (1995), Copepoda. Guides to the identification of the Microinvertebrates of the Continental Waters of the World. SPB Academic Publishing, The Netherlands. 226 pp.

Golterman, H. L. and Clymo, R. S. (1969), Methods for chemical analysis of freshwaters. Blackwell, Oxford. $166 \mathrm{pp}$.

Henry, R. (1990), Amonia ou fosfato como agente estimulador do crescimento do fitoplancton da Represa de Jurumirim (Rio Paranapanema, SP). Rev. Brasil. Biol., 50, 883-892.

Henry, R. (1992), The oxygen deficit in Jurumirim Reservoir (Paranapanema River, São Paulo, Brazil). Jpn. J. Limnol., 53, 379-384.

Henry, R. (1993a), Thermal regime and stability of Jurumirim Reservoir (Paranapanema River, São Paulo, Brazil). Int. Revue ges. Hydrobiol., 78 501-511.

Henry, R. (1993b), Primary production by phytoplankton and its controBrazil). Rev. Brasil. Biol., 53, 489-499.

Henry, R. (1995), The thermal structure of some lakes and reservoirs in Brazil. In: Tundisi, J. G.; Bicudo, C. E. M.; Matsumura-Tundisi, T. (Eds) Limnology in Brazil. ABC/ SBL, Rio de Janeiro. pp.351-364.

Henry, R. and Maricato, F. E. (1996), Sedimentation rates of tripton in Jurumirim Reservoir (São Paulo, Brazil). Limnologica, 2615-25.

Henry, R.; Nunes, M. A.; Mitsuka, P. M.; Lima, N. and Casanovas S. M. C. (1998), Variação espacial e temporal da produtividade primária pelo fitoplâncton na Represa de Jurumirim (Rio Paranapanema, SP). Rev. Brasil. Biol., 58, 571-590.

Hynes, H. B. N. (1970), Ecology of Running Waters. University of Toronto Press Toronto. 555 pp. 
Lansac-Tôha, F. A.; Lima, A. F.; Thomaz, S. M. and Roberto, M. C. (1995), Zooplâncton de uma planície de inundação do rio Paraná, II: Variação sazonal e influência dos níveis fluviométricos sobre a comunidade. Acta Limnol. Brasil., 6, 42-55.

Mackereth, F. J. H.; Heron, J. and Talling, J. F. (1978), Water Analysis: Some Revised Methods for Limnologists. Freshwater Biological Association Scientific Publication 36, Titus Wilson and Sons, Oxford. 117 pp.

Matsumura-Tundisi, T. (1986), Latitudinal distribution of Calanoida Copepods in freshwater aquatic systems of Brazil. Rev. Brasil. Biol., 56, 527-553.

McCauley, R. (1984), The estimation of the abundance and biomass of zooplankton in samples. In: Downing, J. A. and Rigler, F. H.(Eds.) A Manual on Methods for the Assessment of Secondary Productivity in Freshwaters. $2^{\text {nd }}$ ed. Blackwell, Oxford. pp. 228-265.

Neiff, J. J. (1996), Large rivers of South America: toward the new approach. Verh. Internat. Verein. Limnol., 26, 167-180.

Nogueira, M. G. and Panarelli, E. (1997), Estudo da migração vertical das populações zooplanctônicas na Represa de Jurumirim (Rio Paranapanema São Paulo, Brasil). Acta Limnol. Brasil., 9, 55-81.

Palmer, R. and O'Keeffe, J. (1990), Transported material in small rivers with multiple impoundments. Fresh Biol., 24, 563-575.

Payne, A. I. (1986) The Ecology of Tropical Lakes and Rivers. John Wiley and Sons, New York. 301 pp.

Petts, G. E. (1984),Impounded Rivers - Perspectives for Ecological Management. John Wiley and Sons, New York. 326 pp.

Pourriot, R.; Rougier, C. and Miquelis, A. (1997), Origin and development of river zooplankton: example of the Marne. Hydrobiologia, 345, 143-148.

Sendacz, S.; Kubo, E.(1982), Copepoda (Calanoida e Cyclopoida) de reservatórios do Estado de São Paulo. Bol. Inst. Pesca, 9, 51-89.

Strickland, J.D. and Parsons, T.R. (1960), A Manual of Sea Water Analysis. Bull.Fish. Res. Bd. Can, 125, $1-185$.

Tonhasca Jr., A. (1994), Diversity indices in the analysis of biological communities. Ciênc. Cult., 46, 138-140.

Townsend, C. R. and Scarsbrook, M. R. (1997), The intermediate disturbance hypothesis, refugia, and biodiversity in streams. Limnol. Oceanogr., 42 938-949.

Urabe, J. (1989), Relative importance of temporal and spatial heterogeneity in the zooplankton community of an artificial reservoir. Hydrobiologia, 184, 1-6.

Vannote, R. L.; Minshall, W.; Cummins, K. W.; Sedell, J. R. and Cushing, C. E. (1980), The river continuum concept. Can. J. Fish. Aquatic. Sci., 37130-137.

Vásquez, E. and Rey, J. (1989), A longitudinal study of zooplankton along the Lower Orinoco River and its Delta (Venezuela). Annls. Limnol., 25, 107-120.
Ward, J. V. (1975), Downstream fate of zooplankton from a hypolimnial release mountain reservoir. Verh. Internat. Verein. Limnol., 19, 1798-1804

Ward, J. V. and Stanford, J. A. (1982a), Tailwater biota: Ecological response to environmental alterations. Symposium on Surface Water Impoundments, (Minnesota). pp.1516-1525.

Ward, J. V. and Stanford, J. A. (1982b), Thermal responses in the evolutionary ecology of aquatic insects. Ann. Rev. Entomol., 27, 97-117.

Ward, J. V. and Stanford, J. A. (1983), System concepts - The serial discontinuity Concept. In: Fontaine, T. D. and Bartell, S. M. Dynamics of Lotic Ecosystems. Ann. Arbor. Science, 30-42.

Ward, J. V. and Stanford, J. A. (1991), Research directions in stream ecology. Advances in Ecology, 1, 121-132.

Zurek, R. and Dumnicka, K. (1989), The fate of zooplankton in a river after leaving a dam. Arch. Hydrobiol. Beih. Ergebn. Limnol., 33, 549-561.

Received: May 25, 2000; Revised: March 13, 2001; Accepted: August 28, 2001. 